\title{
DEFYING THE CERTIFICATION DIPLOMA FORGERY WITH BLOCKCHAIN PLATFORM: A PROPOSED MODEL
}

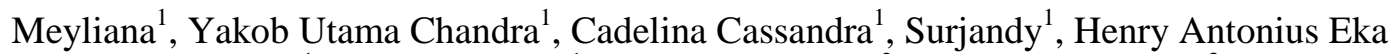 \\ Widjaja $^{1}$, Erick Fernando ${ }^{1}$, Harjanto Prabowo ${ }^{2}$, and Charles Joseph ${ }^{3}$ \\ ${ }^{1}$ Information Systems Department, School of Information Systems, Bina Nusantara University Jakarta, 11480, Indonesia \\ ${ }^{2}$ Computer Science Department, BINUS Graduate Program - Doctor of, Computer Science, Bina Nusantara University \\ Jakarta, 11480, Indonesia \\ ${ }^{3}$ Bloocys Foundation, Pte. Ltd. 079903, Singapore
}

\begin{abstract}
In the University setting, part of management recorded all education transaction since the students register until they graduate. In this point, the transaction raises several new and crucial challenges. At a closer look, the concerns appeared due to no data integration, verification, and validation from parties both inside or outside of the university. In this respect, the data is not centralized or integrated. As this backdrop, this causes repeated data confirmation, and no one can authenticate the data validity when distributed to other parties. In this point of entry, the diploma certification forgery has become one of the significant issues in education in Indonesia. As a framework that enables the data integration, Blockchain contains verified data on every single of a transaction, so the data is trustworthy. With this in mind, this paper aims to discuss the best blockchain model for the university level. This study is qualitative-based research. As a result, McRhys model is introduced as a potential and implementable blockchain model in university in Indonesia.
\end{abstract}

\section{KEYWORDS}

University, Blockchain, McRhys Model, Qualitative Research

\section{INTRODUCTION}

Amid the excitement, people are now experiencing a myriad of technologies enhancement in this digital era. In this context, technology adoption in a different culture transforms people's profession and routine. Bearing this in mind, people interact with a thousand of data and information around the world on daily based. As one of the agents of changes, education institution should offer a creative and distinctive way for all stakeholders to be empowered with technology. With this lens, people talk about data integration for decades. However, the fact recorded that not all information was integrated. In particular, people required data confirmation repeatedly to obtain valid information. In this direction, it spans organizations and people with open opportunities to have solely trusted information media and can be used widely for various purposes should the concept of data integration applied properly. Furthermore, the internet and technology have performed the best mission, not only storing information and communication but also enabling people to start thinking about something innovative invention with a bigger impact. For this voice, we are closer to blockchain concept (Tapscott and Tapscott, 2017) if we think about data-distributed, data-integration, higher security platform, ledger, database, storage, sharing data and connecting people with a real data, unmanipulated, and trustworthy eventually.

Equally important, the blockchain concept is close to the distributed open ledger. With a distributed open ledger, verified stakeholders (Government and industry) will validate all transaction and documents such as diploma certificate and transcript. In the validation and verification stage, the data is more accurate and trustworthy.

Among the researchers, blockchain phenomenon was published by Satoshi Nakamoto (Nakamoto, 2008) in 2008. In his publication, Nakamoto introduced some findings on Proof of Work, Distributed Open Ledger. In that regards, the technology of Blockchain has been used as a popular application presently, and Bitcoin cryptocurrency is the first manifestation (Devecchi et al., 2017). The successful of blockchain framework 
technology has led many Big Companies such as Intel, IBM, Microsoft, to commence the research on blockchain.

Based on the blockchain research recently, blockchain technology can be used in near sectors of the industry due to some values provided by blockchain such as "immutable", "unchangeable", "validated", "shared \& open". The concept of blockchain is very acceptable to support the collaboration, not only for bitcoin, but the blockchain is also widely studied for construction management (Turk and Klinc, 2017). In this perspective, blockchain is close to what we called as identity; every person requires a valid identity and recognition/approval from the government, university, industries, bank, and other relevant sectors. In particular, Blockchain could also be used in the education area. In common practice, the data for educational purpose is not integrated among the stakeholders; no one can approve and recognize your data unless you got certificated and reported. Because of these reasons, blockchain is very suitable to be applied in the education sector or university. Several previous studies researched to implement blockchain in the library process (Hoy, 2017) and also for study loan process (Gazali et al., 2017).

Blockchain is an appealing topic of discussion among industries. In this corridor, the research focused on university blockchain in term of the use of blockchain for Diploma Certificate Issue, which on the certificate contains elements of immutable (cannot be replaced and valid all the time). In a specific context, this research is conducted to overcome the increasing number of forged diplomas abuse (Agriesta, Dheri, 2017). In 2015, the Ministry of Education in Indonesia reported 187 working bogus diploma owner in government ( Linggasari, Yohannie, 2015). These issues were crucial, not only involving students but also the government staff ( Andi Saputra, 2017), ( Nur Aditya, 2017). In other words, this old issue (bbc.com, 2015) is still happening until at present. With this background, these phenomena demand a solution to prevent the issue in the future. In the public sector, The Ministry of Research, Technology and Higher Education has established a team to evaluate this diploma forgery issue (Independensi, 2017).

In university, blockchain model can be described as a collaboration among Government, Corporate/Industry, Institution of Certification, and the University itself that has the same interest to the data of student, alumni, lecturer, or teaching assistant. Based on university desideratum, the researchers create a new proposed blockchain model for university level, which called a "McRhys model" in Indonesia.

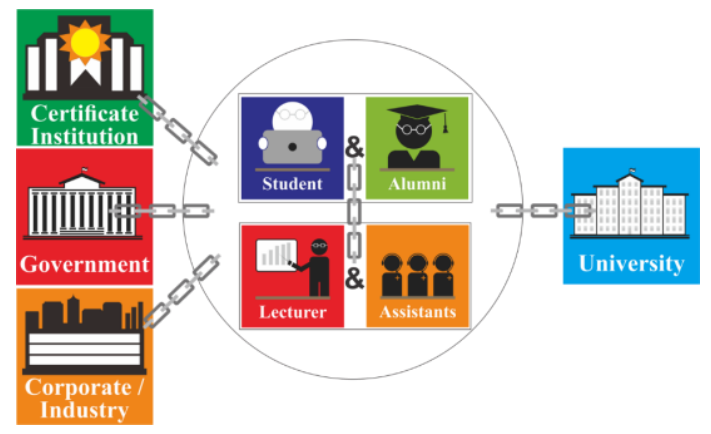

Figure 1. McRhys New Proposed Blockchain Model for University in Indonesia

McRhys is a model to record and integrate all activities in university with blockchain concept. McRhys model emphasizes on "Distributed Open Ledger". The data inside the blockchain is open to all stakeholder of the same interest with the data and information provided by the university. The transaction is validated peer to peer and verified.

The objectives of McRhys is to answer the problems because of a lack of data transparency, validity, and reliability of the score transcript. This score transcript is also used by industry to check the competency of their applicant and workers. Moreover, the industry requires less or no confirmation to the university if the concept of blockchain is applied appropriately. The industry accesses the data with ease to validate the employer.

At this stage, this study proposes two ways of identifying diploma certification fraudulent, namely illegal institutions issuing certificates or official institutions with data counterfeit (student never registered and followed the teaching and learning process, but received a diploma certificate). Based on this background, Blockchain represents a framework that can be used to surmount the problem of diploma certification forgery in education platform. At this line, qualitative research is used on this research to answer the question of 
"How blockchain framework can be implemented to eradicate diploma certification forgery in university?". Moreover, the purpose of this study contributes to promoting the university in ensuring the data reliability and validity of the diploma certification and minimizing the misused information of diploma certification.

\section{LITERATURE REVIEW}

\subsection{Blockchain}

Blockchain is a new technology platform published by Satoshi Nakamoto (Nakamoto, 2008) and is used for almost one decade for cryptocurrency named Bitcoin. The success of Bitcoin drives other company to find the other way to implement blockchain in different industry and business. The concept is a financial transaction but without a financial institution. Bitcoin has become famous recently; there are many other examples of the success of bitcoin such as Litecoin, Peercoin, Ripple, and Ethereum Cryptocurrencies (Hoy, 2017).

Blockchain can also be implemented in the health industry (hospital) (Ahram, Sargolzaei, Sargolzaei, Daniels, \& Amaba, 2017; Azaria, Ekblaw, Vieira, \& Lippman, 2016; Hoy, 2017; Fanning \& P. Centers, 2016; Karafiloski \& Mishev, 2017), Education (Bdiwi, Runz, Faiz, \& Cherif, 2017; Hoy, 2017), Manufacturing (Ahmed, Selena; Broek, 2017; Ahram et al., 2017), Financial (Treleaven, Brown, \& Yang, 2017; Al-Saqaf \& Seidler, 2017; Singh \& Singh, 2016), Government (Hou, 2017), etc. In Education, commonly, blockchain is used for teaching and learning process (Bdiwi, Runz, Faiz, \& Cherif, 2017) and also other research shows that blockchain is possible for the library (Hoy, 2017).

\subsection{How Blockchain works}

Blockchain draws a sequence transaction such as General Ledger. (Zheng et al., 2017). In this frame, every block of blockchain has a hash or layered encryption. Validated data will be arranged in sequence order to be a chain and then distributed (distributed open general ledger).

Furthermore, the Blockchain concept also implements a Proof of Work concept. In this side, Proof of Work is also used in Bitcoin Network (Nakamoto, 2008). Proof of work is needed to validate each activity and create "hash key" in cryptography to ensure the security level for each level of the transaction.

\subsection{Blockchain for University}

Referring to the blockchain's ability to validate data and provide accurate information such as ledgers and their possible use in various fields, this reinforces the role of the blockchain that can be adopted at universities. (Tapscott and Tapscott, 2017). At a closer look, every transaction such as financial and other transaction such as teaching and learning, borrowing books, scoring, certification, can be recorded in the blockchain framework (Grech and Camilleri, 2017)

\section{RESEARCH METHODOLOGY}

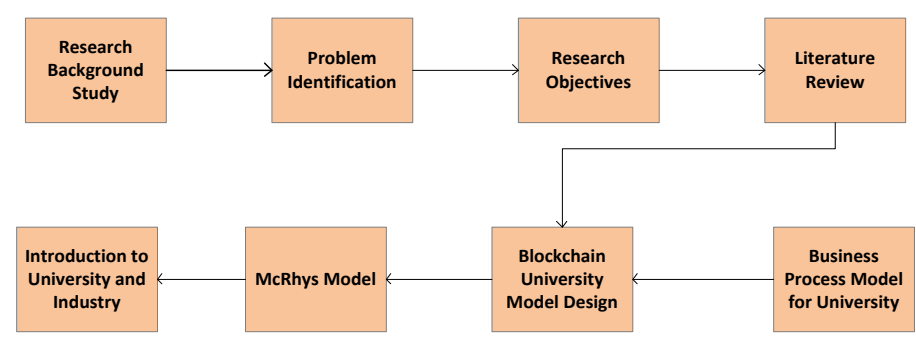

Figure 2. Research Methodology 


\subsection{Research Background Study}

At the initial stage, the researchers found a phenomenon of diploma certificate forgery and highlighted a focal point of discussion and contemporary issue in Indonesia. The problem is not only from the illegal institution but also from the university that has a chance to publish a bogus certificate. In this setting, this is because of no valid verification from another key partner. As a result, a forged certificate leads to fake information and data accuracy. This issue drives the researcher to find the appropriate framework and model to be implemented.

\subsection{Problem Identification}

The research identified the increasing number of forged diploma certificate. In this line, people can obtain or purchase a certificate without joining the teaching and learning process. As described, this forgery symbolized a criminal act, and therefore, the government is required to cease it. It directs the research to find a method, a framework, and an idea on how to issue the real and verified certificate.

\subsection{Research Objectives}

In this part, the researchers defined the research objectives following the specific problem. At the same time, researchers figured out what the need is to solve the problem. The objective of this research is to provide open data and information which is auditable, valid, and reliable so that the students' portfolio and credentials are proven. For another counterpart, this also will help the industry to find the best talent for the company by using this blockchain model.

\subsection{Literature Review}

In this section, a literature review is conducted to help researchers finding the same interest in the topic to support this research. This research centres on blockchain implementation in university. The literature review will be the foundation of the blockchain model for the university.

\subsection{Business Process Model for University}

In this topic, the researchers also delved in and proposed the appropriate business process model for University. At the next level, the researchers decided the best solution for designing the model. As stated, the Business Process Model for University is obtained from the research. The research involved a survey of 58 universities in Jakarta. In this case, it reflects the formulated business model as a result (Meyliana, 2015; Meyliana, Hidayanto, \& Budiardjo, 2015). The researchers applied the BPM model as the foundation for university blockchain.

\subsection{Blockchain University Model Design}

Based on all literature and business process models, Blockchain University Model Design was proposed to describe the overall process in universities and identify entities of each block.

\subsection{McRhys Framework for University}

McRhys Framework is a framework of blockchain for university. The framework shows the data integration and interaction of all stakeholders in the framework. With this framework, the reputations of the parties become indelibly. The research shows that data is always valid and verified for every block. Data is also can be used by other parties without confirming repeatedly. The process of issuing a diploma/bachelor certificate 
will always be validated, and certification forgery is eliminated because of the blockchain implementation. From the lesson, the industry and government will also access data easily.

\subsection{Introduction to Universities and Industries}

Based on the research, it confirmed the implementable state of McRhys Model in 24 universities in Jakarta as respondents. The respondents of selected universities represented top 100 rankings of universities in Indonesia from the Ministry of Research, Technology and Higher Education of the Republic of Indonesia and Webometrics. In this context, the researchers invited the respondents for this socialization stage to introduce the McRhys model.

\section{RESULT AND DISCUSSION}

Based on the business process model and discussion, the study concluded the process into one value chain of core business process in education. Figure 3 described the whole process of the value chain, which leads to the blockchain concept.

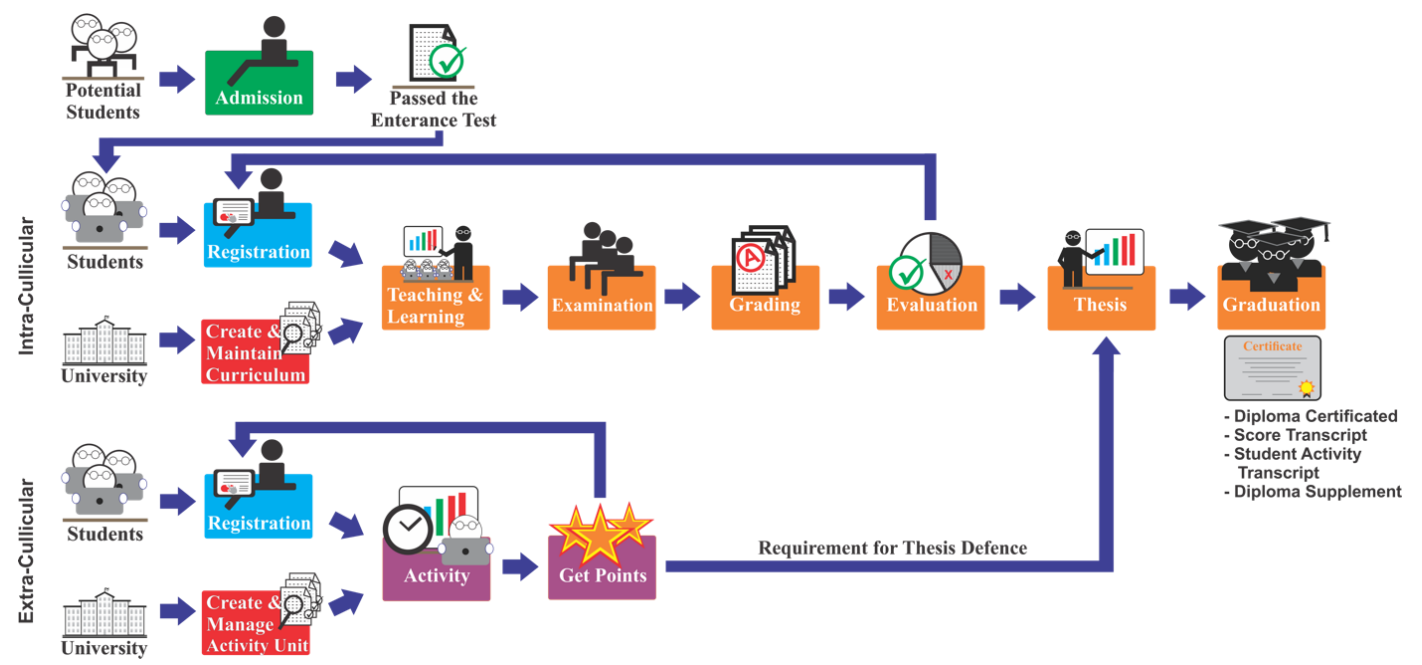

Figure 3. Value Chain of Core Business Processes in Education

\subsection{Intra-curricular}

After the graduation and selection of the intended university for higher education level, high school graduates must follow the registration process to become a university student. On the student side, the student completes all document required to Admission Front Office at first. After all fulfilled requirements, the candidate will take part in the entrance test. The entrance test might be different among universities. It depends on the stipulated standard. The student is required to re-register to become the active student as the candidate passes the test. The student data will be distributed from admission to the Student Registration and Scheduling Center, and the Student Services unit. Following that, the unit schedules the new student into Student Preparation Program. This program is to introduce the university closer to the student.

On the University side, Student Registration and Scheduling Unit creates a Lecture Scheduling by mapping the Lecturers, Students, Venue, and Time. While Academic Supporting Unit creates a curriculum for the faculty department, the faculty department will maintain the academic resources to be distributed to students every semester after the curriculum is published.

During the Teaching and Learning process, the Academic Operation Unit monitors the process and ensures everything is running on the right track. The Academic Operation Unit also records the attendance of lecturers and students. The examination reflects the evaluation process. Usually, the university runs the Mid Term Exam and the Final Exam to evaluate student comprehension holistically. After scoring the 
examination, lecturers input the student score on the Learning Management System provided by the university. Following the process, the Academic Operation Unit and Student Advisory Unit evaluate the score. The result of the score evaluation will determine the student eligibility for graduation. The ministry of higher education will receive the report of the scores and test results every semester through the Rectorate Unit. This process will be repeated every semester until the students graduate from the University.

At the final semester, students are required to take the thesis or final assignment and opt for a supervisor who guides them during the thesis supervision. Student Registration and Scheduling Unit also monitors the process of thesis submission and ensures all of the fulfilled requirements. The requirement such as Grade Point Average (GPA), credit passed, and student activity transcript. Once the student fulfils all the requirement, Student Registration and Scheduling Unit creates a Schedule for thesis defence and chooses examiner panellist who checks and verifies the student comprehension of the thesis. The panellist submits the score to Student Registration, and Scheduling Unit and the unit inputs the score into Learning Management Systems provided by the university.

At the next stage, Academic Operation Unit finalizes all student's score. This result determines the students' eligibility status to receive the graduation document, including Diploma Certificate, Score Transcript, Student Activity Transcript, and Diploma Supplement. The National Government issues a great number of diploma/bachelor certificates, and every student receives a unique code printed on the certificate. The government also receives the report of all eligible student through Rectorate Unit.

\subsection{Extra-curricular}

University manages and recommends student clubs or student association that bring students with the same interest to join activities for self-development in a different context. University facilitates the activities as long as the activity and group are registered and managed well. A student may choose the clubs to join based on the preference. The student accumulates the activity points by joining the activities. The Student Activity Unit evaluates the students and provides a point for students. The authorized centre calculates, inputs the point into the Learning Management System and the Student Activity Transcript as one of the requirements for a student to register for a thesis in the final semester.

\subsection{McRhys Blockchain Student Registration and Course Registration Process}

Figure 4 epitomized the detail of McRhys Model as the recommendation for University Blockchain.

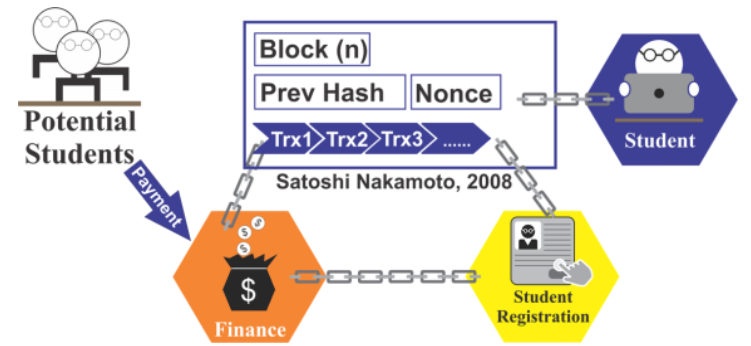

Figure 4. McRhys Blockchain Student Registration and Course Registration

"Genesis Block" or the first block is created when a student is registered and pays the settlement fee. After registration, all parties can access the new student. In this aspect, the parties consist of Marketing, Finance, SRC (Student Resource Center), and Academic Operation.

\subsection{McRhys Blockchain University Scoring List Student Document}

After a student is registered, all transaction will be recorded inside the blockchain such as courses, attendance, lecturer, venue, class, examination, and score. By using this concept, the forged diploma certificate is possible to be reduced because all of the transaction is validated and transparent, immutable, and unchangeable. The following process exhibits the detail of process on how McRhys model will help in fighting diploma certificate forgery issue. Figure 5 summarized the scoring based on McRhys Model. 


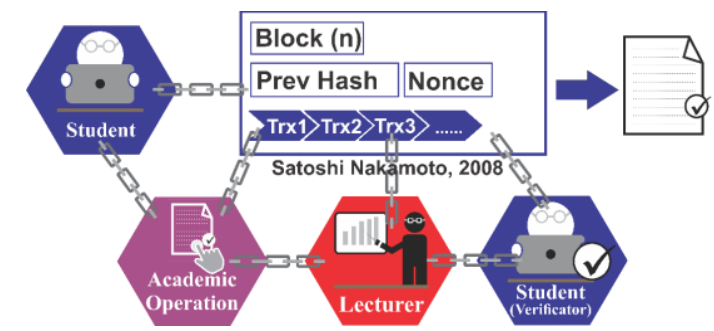

Figure 5. McRhys Blockchain University Scoring List Student Document

\subsection{McRhys Blockchain University Diploma Certification}

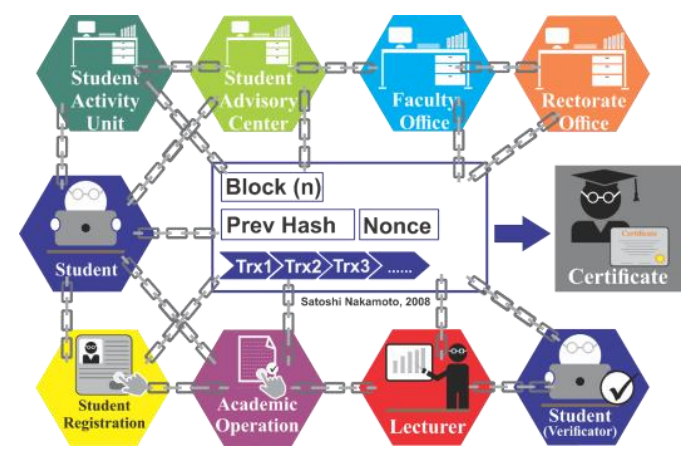

Figure 6. McRhys Blockchain University Diploma Certification

After a complete transaction, this step determines the eligibility of graduation. All decisions that will be permanently recorded and cannot be altered will be distributed to all related persons within this community. The use of blockchain in the education industry is possible because of the Immunity concept. The number of diploma certificates and the score transcripts are recorded in the certificate.

Figure 7 exhibits all transactions captured on the block and verified by the counterpart. For instance, the finance and student registration will verify student payment of the tuition fee and the transaction. The student will verify the courses schedule provided by the academic operation. For another example, when the student attends the class, the transaction will be verified by another student (verification) in the class (prefect) and the lecturer. Thus, figure 7 shows all the student transactions in the university that will be distributed to all parties after verification, validation, and the data is immutable. Therefore, the blockchain university transaction list can produce evidence of student attendance in the course. It means that the reliability and validity of university scoring list document can fight the forged data of diploma certificate. After students enrol in the last semester, the data of students will be submitted to the government, and they receive the registered number of diploma certification. The registered number will be published when students fulfil all requirements. All the transaction will be recorded to the blockchain university transaction.

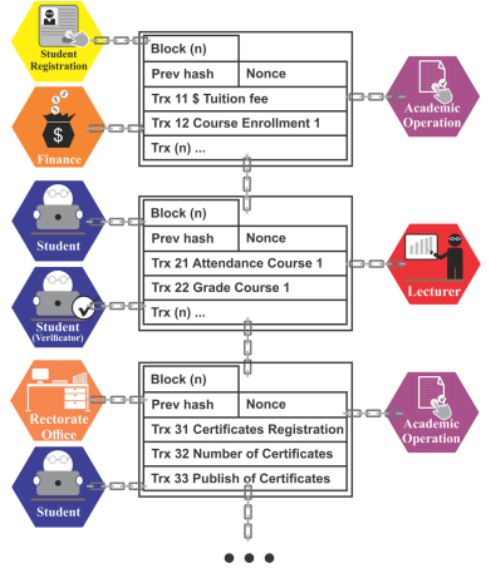

Figure 7. McRhys Blockchain University Transaction List 


\section{CONCLUSION}

New proposed McRhys blockchain model is created based on the value chain of core business process in 58 universities in Indonesia. The data integration and centralized information offered by blockchain are similar to open data and general ledger. In this context, stakeholders can access the same data, and the data can be validated real-time. At the same time, this condition will keep the data up-to-date, validated, verified and accurate.

This concept of blockchain can solve the problem such as diploma certificate forgery which is an important contemporary issue nowadays in Jakarta. Because of no data validation, this provides an opportunity for a criminal to make a bogus diploma certification and sell it to people who requested. Not only illegal institution can provide this certification, but the universities can also publish diploma certification forgery. To anticipate this, McRhys model is proposed, which is driven by the blockchain model. In this scope, it offers data integration. It reflects that this concept is crucial for the university to keep the data validity and support the government to eradicate the diploma certification forgery.

\section{IMPLICATION}

In this research, the implication of this model will assist the university in Indonesia to obtain data validity without re-confirming the data repeatedly. This model is also bolstering the industry easier and more convenience in acquiring the background of their applicant and undertaking the verification. In this vein, the industry can hire an employee based on their preference and authorized data as well as repudiate data counterfeit.

\section{LIMITATION AND FUTURE RESEARCH}

This research is focusing on how blockchain can solve the problem of fake diploma certification. The result is an integrated value chain of core business processes, which allows the implementation of the blockchain model. Importantly, blockchain can solve many problems more than the diploma certificate issue. It highlights that future research should identify the different point of view of this research, elaborate more issue because of the novelty of this research area in education. In the future, blockchain technology and integration should be designed and implemented to provide evidence of data integration for university.

\section{ACKNOWLEDGEMENT}

This work is supported by the Directorate General of Strengthening for Research and Development, Ministry of Research, Technology, and Higher Education, Republic of Indonesia as a part of Penelitian Terapan Unggulan Perguruan Tinggi Research Grant to Binus University entitled "Implementasi Blockchain Platform untuk Menciptakan "Good Governance" pada Perguruan Tinggi" or "The Implementation of Blockchain Platform to Create "Good Governance" in Higher Education" with contract number: 12/AKM/PNT/2019 and contract date: 27 March 2019.

\section{REFERENCES}

Ahmed, Selena; Broek, N. ten, 2017. Blockchain Could boost food security. Nature, 550(7674), p. 43. DOI: $10.1038 / 550043 \mathrm{e}$.

Ahram, T. et al., 2017. Blockchain technology innovations. 2017 IEEE Technology and Engineering Management Society Conference, TEMSCON 2017, (2016), pp. 137-141. DOI: 10.1109/TEMSCON.2017.7998367.

Al-Saqaf, W. and Seidler, N, 2017. Blockchain technology for social impact: opportunities and challenges ahead, Journal of Cyber Policy. Taylor \& Francis, 0(0), pp. 1-17. DOI: 10.1080/23738871.2017.1400084. 
Azaria, A. et al., 2016. MedRec: Using blockchain for medical data access and permission management. Proceedings 2016 2nd International Conference on Open and Big Data, OBD 2016, pp. 25-30. DOI: 10.1109/OBD.2016.11.

Bdiwi, R. et al., 2017. Towards a New Ubiquitous Learning Environment Based on Blockchain Technology. 2017 IEEE 17th International Conference on Advanced Learning Technologies (ICALT), pp. 101-102. DOI: 10.1109/ICALT.2017.37.

Devecchi, C. et al., 2017. Blockchain Educational Passport Blockchain Educational Passport: Decentralised Learning Ledger (DLL) Preceding white papers Proof-of-Concept: Authors. Development Heads: Sajin Abdu (Technology), (Dll).

Fanning, K. and P. Centers, D,2016. Managing financial risk. Australian Journal of Pharmacy, 85(1011), pp. 440-441. DOI: $10.1002 /$ jcaf.

Gazali, H. M. et al., 2017. Re-inventing PTPTN study loan with blockchain and smart contracts. ICIT 2017 - 8th International Conference on Information Technology, Proceedings, pp. 751-754. DOI: 10.1109/ICITECH.2017.8079940

Grech, A. and Camilleri, A. F, 2017. Blockchain in Education. JRC Science for Policy Report. DOI: 10.2760/60649.

Hoy, M. B, 2017. An Introduction to the Blockchain and Its Implications for Libraries and Medicine. Medical Reference Services Quarterly. Taylor \& Francis, 36(3), pp. 273-279. DOI: 10.1080/02763869.2017.1332261.

Agriesta, Dheri, 2017. Menristek Dikti Minta Seluruh Pembuat Ijazah Palsu Ditangkap. medcom.id. 12 August 2017 [online]. Available at https://www.medcom.id/nasional/hukum/zNPdxngN-menristek-dikti-minta-seluruh-pembuatijazah-palsu-ditangkap (Accessed: 1 December 2018)

Karafiloski, E. and Mishev, A, 2017. Blockchain solutions for big data challenges: A literature review. 17th IEEE International Conference on Smart Technologies, EUROCON 2017 - Conference Proceedings, (July), pp. 763-768. DOI: 10.1109/EUROCON.2017.8011213.

Nur Aditya, 2017. Kasus ijazah palsu, ketua lembaga pendidikan di Samarinda ditangkap. merdeka.com. 20 October 2017[online]. Available at https://www.merdeka.com/peristiwa/kasus-ijazah-palsu-ketua-lembaga-pendidikan-disamarinda-ditangkap.html (Accessed : 1 December 2018)

Saputra, Andi, 2017. MA Makzulkan Bupati Mimika karena Kasus Ijazah Palsu. detik.com. 26 November 2017[online]. Available at https://news.detik.com/berita/d-3743651/ma-makzulkan-bupati-mimika-karena-kasus-ijazah-palsu (Accessed : 1 December 2018)

Linggasari, Yohannie, 2015. Menteri Nasir: 187 Pemilik Ijazah Palsu Punya Jabatan Penting. cnnindonesia.com. 27 May 2015[online]. Available at https://www.cnnindonesia.com/nasional/20150527145913-20-56045/menteri-nasir187-pemilik-ijazah-palsu-punya-jabatan-penting (Accessed : 1 December 2018)

Meyliana (2015) Social CRM in Higher Education: Model, Process, Channel Preference, and Critical Success Factors (Doctoral Dissertation). University of Indonesia.

Meyliana, Hidayanto, A. N. and Budiardjo, E. K, 2015. Evaluation of social media channel preference for student engagement improvement in universities using entropy and topsis method. Journal of Industrial Engineering and Management, 8(5), pp. 1676-1697. DOI: 10.3926/jiem.1652.

Nakamoto, S, 2008. Bitcoin: A Peer-to-Peer Electronic Cash System. Www.Bitcoin.Org, p. 9. DOI: $10.1007 / \mathrm{s} 10838-008-9062-0$.

bbc.com, 2015. Praktek ijazah palsu perlu 'pengawasan ketat. bbc.com. 4 June 2015[online]. Available at https://www.bbc.com/indonesia/berita_indonesia/2015/06/150603_indonesia_ijazah_palsu (Accessed: 1 December 2018)

Singh, S. and Singh, N.,2016. Blockchain: Future of financial and cybersecurity. Proceedings of the 2016 2nd International Conference on Contemporary Computing and Informatics, IC3I 2016, pp. $463-467$. DOI: 10.1109/IC3I.2016.7918009.

Tapscott, D. and Tapscott, A., 2017. The Blockchain Revolution and Higher Education. EDUCAUSE Review, pp. 10-24. DOI: $10.1038 / 308683 \mathrm{~b} 0$.

Independensi, 2017. Tim Evaluasi Kemendikti Pastikan Jual Beli Ijazah di Universitas Negeri Jakarta. Independensi.com. 22 September 2017[online]. Available at https://independensi.com/2017/09/22/tim-evaluasikemendikti-pastikan-jual-beli-ijazah-di-universitas-negeri-jakarta/ (Accessed: 1 December 2018)

Treleaven, P., Brown, R. G. and Yang, D., 2017. Blockchain Technology in Finance. Computer, 50(9), pp. 15-17. DOI: 10.1109/MC.2017.3571047.

Turk, Ž. and Klinc, R., 2017. Potentials of Blockchain Technology for Construction Management. Procedia Engineering. The Author(s), 196(June), pp. 638-645. DOI: 10.1016/j.proeng.2017.08.052.

Zheng, Z. et al.,2017. An Overview of Blockchain Technology: Architecture, Consensus, and Future Trends. Proceedings - 2017 IEEE 6th International Congress on Big Data, BigData Congress 2017, pp. 557-564. DOI: 10.1109/BigDataCongress.2017.85. 